ROCZNIKI NAUK PRAWNYCH

Tom XXXI, numer $2-2021$

DOI: https://doi.org/10.18290/rnp21312-4

SZYMON MOŚ

\title{
SAMODZIELNOŚĆ WYDATKOWANIA ŚRODKÓW PUBLICZNYCH A SAMORZĄDOWY PROGRAM POLITYKI ZDROWOTNEJ
}

\begin{abstract}
WSTĘP
Celem niniejszego artykułu jest wykazanie, że przy opracowywaniu samorządowego programu polityki zdrowotnej (dalej: s.p.p.z.) występuje systemowa niespójność pomiędzy sferą samodzielności wydatkowania środków publicznych przez jednostkę samorządu terytorialnego (dalej: j.s.t.) a wydawaną $\mathrm{w}$ toku procedury opracowywania projektu takiego programu opinią Prezesa Agencji Oceny Technologii Medycznych i Taryfikacji ${ }^{1}$. Samodzielność wydatkowania środków publicznych przez j.s.t. - jako przejaw samodzielności finansowej samorządu terytorialnego - nie ma wprawdzie charakteru absolutnego i doznaje ograniczeń, a podobnie jak pozostała aktywność j.s.t. podlega nadzorowi, nadzór ten jest jednakże podmiotowo i przedmiotowo ściśle określony i oparty na precyzyjnie zdefiniowanych kryteriach.

Tymczasem $\mathrm{w}$ procedurze opracowywania projektu s.p.p.z. (jako formy realizacji zadań j.s.t. w sferze ochrony zdrowia), który zawiera się we wspomnianej już samodzielności wydatkowej (finansowanie programu jest następstwem decyzji podjętej przez j.s.t.), przewidziano istotny udział Prezesa AOTMiT. Brak pozytywnej opinii tego, pozostającego w strukturze administracji rządowej ${ }^{2}$ i nadzorowanego przez ministra właściwego do spraw

\footnotetext{
Mgr Szymon Moś - asystent Katedry Prawa Finansowego na Wydziale Prawa i Administracji

${ }^{1}$ Dalej: Prezes lub Prezes AOTMiT, instytucja zaś jako: AOTMiT.

${ }^{2}$ Por. Druk nr 1590, Sejm Rzeczypospolitej Polskiej VI kadencji, http://orka.sejm.gov.pl/
} Uniwersytetu Gdańskiego, ul. Bażyńskiego 6, 80-309 Gdańsk; e-mail: szymon.mos@ug.edu.pl; ORCID: https://orcid.org/0000-0001-7857-4838. Druki6ka.nsf/0/097002D1CC0F4D2DC12575450030C90B/\$file/1590.pdf, s. 35 (s. 10 uzasadnienia) [dostęp: 3.02.2021].
\end{abstract}


zdrowia organu, uniemożliwia bowiem realizację s.p.p.z. Przyjęto zatem hipotezę badawczą, że tak silne oddziaływanie kolidować może z samodzielnością wydatkową j.s.t. w kontekście zasad nadzoru nad wydatkowaniem przez te jednostki środków publicznych. Przyjętą hipotezę poddano weryfikacji przy zastosowaniu metody formalno-dogmatycznej, odwołując się do tekstów aktów prawnych oraz dokonując ich wykładni, a także przywołując poglądy doktryny i orzecznictwa.

Sformułowano także postulaty de lege fenda uwzględniając okoliczność, że realizacja zadań publicznych przez j.s.t., nakierowanych przede wszystkim na interes wspólnoty lokalnej ${ }^{3}$, nie pozostaje w ustrojowej próżni. Relacje funkcjonalne, instytucjonalne i gospodarcze, również z organami władzy centralnej, znajdują więc swoje odzwierciedlenie w formie i sposobie realizowania ustawowo wskazanych zadań. Dlatego też przedstawione propozycje nie kwestionują ogólnej zasadności udziału AOTMiT w procedurze opiniowania s.p.p.z.

\section{SAMODZIELNOŚĆ WYDATKOWANIA ŚRODKÓW PUBLICZNYCH PRZEZ JEDNOSTKI SAMORZĄDU TERYTORIALNEGO}

Omawiając samodzielność wydatkowania środków publicznych (dalej: samodzielność wydatkowania) przez j.s.t., należy rozpocząć od zagadnienia samodzielności finansowej. Pojęcie to zasadniczo odnosi się do gospodarowania szeroko ujmowanym mieniem samorządowym, t.j. podejmowania określonych aktywności w zakresie finansowym (publiczno- i prywatnoprawnym), gospodarczym czy handlowym. Samodzielność finansowa dotyczy zwłaszcza możliwości uzyskiwania przez j.s.t. dochodów publicznych oraz prawa do ich wydatkowania na wybrane cele w zakresie przypisanych zadań ${ }^{4}$. W tym ujęciu stanowi ona wyznacznik prawnej i faktycznej pozycji ustrojowej samorządu terytorialnego ${ }^{5}$. Z uwagi na tematykę niniejszego artykułu,

\footnotetext{
${ }^{3} \mathrm{~W}$ doktrynie wskazuje się, że pogodzenie interesu publicznego na poziomie centralnym i interesu lokalnego jest niełatwe - zob. in extenso uwagi M. Mączyńskiego (M. MĄCZYŃSKI, Pojęcie zadania publicznego a zadania samorzadu terytorialnego, „Finanse Komunalne” 2019, nr 1-2, s. 109-110).

${ }^{4}$ Por. P. ChadaŁA, Samodzielność finansowa jednostek samorzadu terytorialnego, „Annales Universitatis Mariae Curie-Skłodowska", Sectio H, Oeconomia 2002, nr 36, s. 227-229.

${ }^{5}$ Zob. poczynione $\mathrm{w}$ okresie międzywojennym rozważania R. Rybarskiego, z których przebija się dopiero kształtujący się ustrój samorządowy II RP (R. RYBARSKI, Nauka skarbowości, Warszawa: Wolters Kluwer 2015 (reprint), s. 388-395. Zob. także: M. KotUlSKI, Samorząd terytorialny $w$ dwudziestoleciu międzywojennym, „Acta Universitatis Wratislaviensis”. Prawo 2019, nr 327, s. 149-151).
} 
przedmiotem analizy będzie, stanowiąca element samodzielności finansowej, samodzielność wydatkowania przez j.s.t. środków publicznych.

Istotą samodzielności wydatkowania są przede wszystkim odpowiednie mechanizmy prawne, umożliwiające j.s.t. swobodę podejmowania decyzji finansowych ${ }^{6}$. Brak gwarancji prawnych, zapewniających możliwości decydowania o wydatkowaniu, unicestwia bowiem samodzielność, niezależnie od zagwarantowanego zasobu środków pieniężnych po stronie dochodowej. Dochodowy aspekt samodzielności finansowej, kluczowy w kontekście nałożonych na samorząd terytorialny zadań własnych, funkcjonalnie wydaje się wtórny wobec samodzielności wydatkowania. Teoretycznie rzecz ujmując, nawet nieograniczone środki pieniężne postawione do dyspozycji j.s.t. przy sztywnym zdefiniowaniu wydatków nie przełożą się bowiem w ogólności na samodzielność finansową ${ }^{7}$.

Samodzielność wydatkowania nie ma charakteru absolutnego ${ }^{8}$. Jest ona, po pierwsze, ograniczona ramami prawnymi zadań samorządu terytorialnego - jako ich pochodna. Ich zakres jest wypadkową realizacji zasady pomocniczości (ewolucyjnie szczególnie związanej ze społeczną nauką Kościoła9). Samodzielność w tym aspekcie wzmacnia szeroki katalog zadań własnych samorządu, co do których dysponuje on możliwością prowadzenia własnej

${ }^{6}$ Decyzję finansową należy tu rozumieć jako „decyzje o charakterze ogólnym i abstrakcyjnym [...] które stanowią podstawę prawną [...] do późniejszego podejmowania różnych czynności związanych z procesami wyrażonymi w pieniądzu (J.M. SALACHNA, Granice samodzielności legislacyjnej jednostek samorządu terytorialnego, Gdańsk: Ośrodek Doradztwa i Doskonalenia Kadr 2012, s. 85).

${ }^{7}$ Należałoby wówczas postawić pytanie, czy ograniczony w decyzjach redystrybucyjnych twór ma jeszcze przymiot samorządności, czy też jest jedynie wykonawcą założeń przyjętych przez władzę centralną państwa - por. M. Poniatowicz, Determinanty autonomii dochodowej samorzadu terytorialnego w Polsce, „Financial Sciences - Nauki o Finansach” 24 (2015), nr 1 (22), s. 17-18, a także J. GLINIECKA, Zasady polskiego prawa dochodów samorządu terytorialnego, Bydgoszcz: Oficyna Wydawnicza Branta 2001, s. 21-23.

${ }^{8}$ Zob. K. SURówKA, Samodzielność finansowa samorzadu terytorialnego w Polsce, Warszawa: Państwowe Wydawnictwo Ekonomiczne 2013, s. 109-114, a także B. KuCIA-GuściorA, Wybrane instrumenty oddziaływania ministra właściwego do spraw finansów publicznych na gospodarkę rynkowa jednostek samorzadu terytorialnego, [w:] Księga jubileuszowa ku czci Profesor Krystyny Sawickiej, red. W. Miemiec, Wrocław: Oficyna Wydawnicza UNIMEX 2017, s. 123-137.

${ }^{9}$ Por. E. KoRnBERGER-SOKOŁOWSKA, Zasada proporcjonalności a ochrona samodzielności finansowej jednostek samorzadu terytorialnego, [w:] Prawo finansowe samorzadu terytorialnego. Prawo finansowe wobec wyzwań XXI wieku, red. J. Gliniecka [i in.], Gdańsk-NynäshamnSztokholm: CeDeWu 2013, s. 36-37. Dodatkowo - jak wskazuje P. Śwital powołując się na S. Fundowicza - samo „słowo 'wspólnota' trafiło także do polskiego języka prawnego i prawniczego z języka religijnego, teologicznego" (P. ŚwITAL, Prawo miejscowe jako podstawa funkcjonowania lokalnej wspólnoty samorządowej, „Samorząd Terytorialny” 2019, nr 11, s. 29). 
polityki publicznej ${ }^{10}$. Z ekonomicznego punktu widzenia, nawet w obrębie tego katalogu można wyróżnić j.s.t. mniej i bardziej samodzielne ${ }^{11}$, jest to jednak następstwo określonych stanów faktycznych, które nie wpływają na gwarancje formalnoprawne, takie same dla wszystkich szczebli samorządu terytorialnego ${ }^{12}$.

Po drugie, wykonywanie samodzielności wydatkowania w obrębie zadań samorządu terytorialnego podlega nadzorowi ${ }^{13}$. Czynności nadzorcze łączą uprawnienia kontrolne w sferze wydatków j.s.t z rozstrzygnięciami o charakterze władczym, dokonywanymi ex post. Nie dochodzi zatem do ingerencji w proces decyzyjny organów samorządu, a zastosowanie ewentualnych środków o charakterze władczym następuje chronologicznie po decyzji właściwego organu j.s.t., podjętej w ramach samodzielności wydatkowania ${ }^{14}$.

Analizując rozwiązania dogmatyczne w tym zakresie, należy przywołać zwłaszcza art. 16 ust. 2 Konstytucji Rzeczypospolitej Polskiej z dnia 2 kwietnia 1997 r. ${ }^{15} \mathrm{~W}$ szczególności wraz z przepisami rozdziału VII stanowi on podstawę przyznania samorządowi terytorialnemu określonego zakresu zadań. Gros materii, również co do unormowań dotyczących samodzielności finansowej j.s.t., pozostawiono do uregulowania aktem rangi ustawowej ${ }^{16}$.

$\mathrm{Na}$ pierwszy plan spośród szeregu ustaw wyznaczających zakres zadań j.s.t. wysuwają się te regulujące ustrój samorządu terytorialnego ${ }^{17}$. Określają one ich zadania własne, a także przyznają cały szereg praw dotyczących gospodarki finansowej, ustalania planów finansowych i gospodarowania majątkiem ${ }^{18}$. Regulacje prawnofinansowe dotyczące samorządu terytorialnego

\footnotetext{
${ }^{10}$ Nie należy tego utożsamiać z dowolnością działań samorządu - por. A. BORODO, Procedury wzakresie wydatków budżetowych jednostek samorzadu terytorialnego - wybrane aspekty prawne, [w:] Ksiega jubileuszowa ku czci Profesor Krystyny Sawickiej, s. 351-352.

${ }^{11}$ Por. A. Kopańska [i in.], Autonomia fiskalna $i$ jej wplyw na dziatania samorzadu, Warszawa: Wydawnictwo Naukowe SCHOLAR 2018, s. 30-42.

${ }^{12}$ Zob. J. ZAWORA, Samodzielność finansowa samorządu gminnego, Rzeszów: Wydawnictwo Uniwersytetu Rzeszowskiego 2008, s. 19.

${ }^{13}$ Zob. K. SURÓwKA, Samodzielność finansowa, s. 109-111.

${ }^{14}$ Por. J. GlumińsKA-PAWLIC, Samodzielność finansowa jednostek samorzadu terytorialnego w Polsce. Studium finansowoprawne, Katowice: Wydawnictwo Uniwersytetu Śląskiego 2003, s. 216-217.

${ }^{15}$ Dz.U. z 1997 r., Nr 78, poz. 483 z późn. zm. [dalej: Konstytucja].

${ }^{16}$ Por. J. GlumińsKa-Pawlic, Samodzielność finansowa, s. 55-56.

${ }^{17}$ Ustawa z dnia 8 marca 1990 r. o samorządzie gminnym, t.j. Dz.U. z 2020 r., poz. 713 z późn. zm. [dalej: u.s.g.]; ustawa z dnia 5 czerwca 1998 r. o samorządzie powiatowym, t.j. Dz.U. z 2020 r., poz. 920 [dalej: u.s.p.]; ustawa z dnia 5 czerwca 1998 r. o samorządzie województwa, t.j. Dz.U. z 2020 r., poz. 1668 z późn. zm. [dalej: u.s.w.].

${ }^{18}$ Zob. J. GLumiŃSKA-PAWLIC, Samodzielność finansowa, s. 60-61.
} 
zawarte są także w ustawie o finansach publicznych ${ }^{19}$. Odnośnie do wydatkowania dotyczą one m.in. zasad gospodarowania środkami publicznymi. W obszarze zaś ochrony zdrowia ustawą regulującą zadania samorządu terytorialnego będzie m.in. ustawa z dnia 27 sierpnia 2004 r. o świadczeniach opieki zdrowotnej finansowanych ze środków publicznych ${ }^{20}$.

Konstytucja RP normuje również nadzór nad działalnością j.s.t., wprowadzając dychotomiczny podział nadzorowanych obszarów pomiędzy podmioty nadzorujące. Mianowicie sprawy finansowe samorządu oddane są we właściwość regionalnych izb obrachunkowych ${ }^{21}$, pozostałe zaś - Prezesa Rady Ministrów i wojewodów ${ }^{22}$. Jako jedyne stosowane kryterium nadzorcze wskazane zostało kryterium legalności. Niewątpliwie wzmacnia to samodzielność wydatkowania samorządu, bowiem władza centralna nie dysponuje narzędziem mogącym kwestionować zasadność (potrzebę) dokonania określonego wydatku, o ile mieści się on w katalogu zadań własnych j.s.t. ${ }^{23}$ Innymi słowy, jeżeli dane zadanie, na realizację którego określona decyzja finansowa kieruje środki pieniężne pozostające $w$ dyspozycji j.s.t., mieści się w zakresie dozwolonych zadań samorządu, brak jest podstawy do jej kwestionowania - na przykład z uwagi na różnicę zapatrywań co do zasadności danego działania przez administrację rządową ${ }^{24}$. Ponadto - jak już wspomniano - czynności nadzorcze dokonywane są ex post. Niemożliwa jest zatem co do zasady również ingerencja $\mathrm{w}$ tok procesu decyzyjnego organów j.s.t. Jeżeli nawet dopuszcza się aktywność organów nadzoru w trakcie przebiegu procesu decyzyjnego, to ma ona charakter niewiążący, przybierając formę opinii (na przykład w przypadku określonych działań $\mathrm{RIO}^{25}$ ).

\footnotetext{
${ }^{19}$ Ustawa z dnia 27 sierpnia 2009 r. o finansach publicznych, t.j. Dz.U. z 2021 r., poz. 305 [dalej: u.f.p.].

${ }^{20}$ T.j. Dz.U. z 2021 r., poz. 1285 [dalej: u.ś.o.z.]. Spośród pozostałych aktów wskazać można szczególnie na ustawę z dnia 15 kwietnia 2011 r. o działalności leczniczej, t.j. Dz.U. z 2021 r., poz. 711.

${ }^{21}$ Działanie izb reguluje ustawa $\mathrm{z}$ dnia 7 października $1992 \mathrm{r}$. o regionalnych izbach obrachunkowych, t.j. Dz.U. z 2019 r., poz. 2137. Izby dalej: RIO (w odpowiednim kontekstowi przypadku i liczbie).

${ }^{22}$ Por. art. 171 ust. 1 i 2 Konstytucji RP. Zob. szerzej: J.M. SAlACHNA, Funkcja ustrojowa Regionalnych Izb Obrachunkowych, „Finanse Komunalne” 2018, nr 12, s. 7-15, a także: A. SylwestrZAK, Regionalne Izby Obrachunkowe w III Rzeczypospolitej Polskiej, „Gdańskie Studia Prawnicze" 2002, nr 8, s. 81-104.

${ }^{23}$ Oraz zadań zleconych, co jednak pozostaje poza zakresem niniejszych rozważań.

${ }^{24}$ Brak hierarchicznego podporządkowania zwiększa samodzielność samorządu - zob. szerzej np. M. KisAŁA, Skuteczność jako determinanta działań jednostek samorzadu terytorialnego, „Studia Prawnicze KUL” 2019, nr 2, s. 181-182.

${ }^{25}$ Por. art. 91 ust. 2 u.f.p. oraz art. 238 ust. 2 u.f.p., por. też art. 230 ust. 5 w zw. z ust. 4 tego artykułu w u.f.p.
} 


\section{OGÓLNE UWAGI O PROCEDURZE OPRACOWYWANIA SAMORZĄDOWEGO PROGRAMU POLITYKI ZDROWOTNEJ}

Ochrona zdrowia jest zadaniem własnym j.s.t., których rola w tym obszarze została im przypisana poszczególnymi ustawami regulującymi ich ustrój oraz u.ś.o.z. ${ }^{26}$ (wypełniając przy tym dyspozycję przepisów konstytucyjnych ${ }^{27}$ ). Globalnie, udział samorządowych środków pieniężnych w finansowaniu opieki zdrowotnej ze środków publicznych ma charakter uzupełniający, odzwierciedlając rolę j.s.t. w ogólnym systemie ochrony zdrowia ${ }^{28}$, w którym jednostki te pełnią przede wszystkim istotne zadania organizacyjne ${ }^{29}$. W kontekście tychże zadań obszar finansowania pozostaje kwestią drugorzędną ${ }^{30}$.

Samorządowy program polityki zdrowotnej, normowany przepisami u.ś.o.z. ${ }^{31}$, jest przejawem działalności j.s.t. właśnie w sferze lokalnego finansowania świadczeń opieki zdrowotnej ${ }^{32}$. Określenie „samorządowy” uzasadnione jest wskazaniem na realizatora programu (taki program może bowiem realizować i finansować także minister ${ }^{33}$ ). Ustawa definiuje program polityki zdrowotnej jako ,zespół zaplanowanych i zamierzonych działań z zakresu opieki zdrowotnej ocenianych jako skuteczne, bezpieczne i uzasadnione, umożliwiających osiągnięcie w określonym terminie założonych celów, polegających na wykrywaniu i zrealizowaniu określonych potrzeb zdrowotnych oraz poprawy stanu zdrowia określonej grupy świadczeniobiorców"34.

${ }^{26}$ Por. art. 7 ust. 1 pkt 5 u.ś.o.z., art. 4 ust. 1 pkt 2 u.s.p., art. 14 ust. 1 pkt 2 u.s.w., a także art. 7-9 i n. u.ś.o.z.

${ }^{27}$ Por. art. 68 ust. 2 Konstytucji RP.

${ }^{28}$ Opartym na modelu publicznoprawnego ubezpieczenia zdrowotnego, z dominującą rolą Narodowego Funduszu Zdrowia jako podmiotu zarządzającego środkami publicznymi przeznaczonymi na finansowanie świadczeń opieki zdrowotnej, pochodzącymi przede wszystkim ze składki zdrowotnej (por. art. 97 u.ś.o.z.).

${ }^{29}$ Por. P. LENIO, Publicznoprawne źródła finansowania ochrony zdrowia, Warszawa: Wolters Kluwer 2018, s. 172-173.

${ }^{30}$ Nie należy jednak finansowania tego marginalizować - może ono adresować istotne problemy w obszarze rozwiązywania kwestii zdrowotnej dla wspólnoty lokalnej.

${ }^{31}$ Zob. przepisy dz. II rozdz. 4 u.ś.o.z. (art. 48 i n.) w zw. z art. 5 pkt 29a tej ustawy.

${ }^{32} \mathrm{O}$ uzupełniającej roli środków $\mathrm{z}$ budżetów j.s.t. jako źródła finansowania systemu ochrony zdrowia zob. P. BIAŁYNICKI-BIRULA, Zmiany w systemie finansowania ochrony zdrowia w Polsce. Perspektywa międzynarodowa, Kraków: Wydawnictwo Uniwersytetu Ekonomicznego w Krakowie 2006, s. 75-76.

${ }^{33}$ Stąd też część uwag czynionych w niniejszej części artykułu do programów polityki zdrowotnej odnosi się zarówno do programów realizowanych przez j.s.t, jak i ministra.

${ }^{34}$ Art. 5 pkt 29a u.ś.o.z. 
Celem programu polityki zdrowotnej są zatem zarówno działania lecznicze, jak i profilaktyka. Chociaż decyzję o realizowaniu programu podejmuje j.s.t., to jego opracowanie podlega ścisłej procedurze, wymaga konieczności dostosowania się do ustawowych wzorców i poddania projektu programu ocenie $^{35}$. Definicja legalna programu polityki zdrowotnej posługuje się jedynie ogólną charakterystyką kryteriów tej oceny (skuteczność, bezpieczeństwo, zasadność). Analiza procedury opracowywania programu polityki zdrowotnej przesłanki te jednak uszczegółowia - wyróżnić można zwłaszcza dwie szczegółowe grupy kryteriów: efektywności medycznej i efektywności kosztowo-finansowej. Wśród elementów programu polityki zdrowotnej przejawia się zaś silny nacisk na mierzalność efektów, mierniki efektywności i ewaluację - zarówno w obszarze zagadnienia medycznego (choroby lub problemu zdrowotnego), jak i kwestii kosztów oraz budżetowania programu ${ }^{36}$.

Ponadto, do procedury opracowywania programu polityki zdrowotnej włączono Prezesa AOTMiT, jako podmiot opiniujący projekt tego programu (negatywnie, pozytywnie lub warunkowo pozytywnie) ${ }^{37}$. Szczegółowe omawianie roli Prezesa $\mathrm{w}$ tej procedurze wykracza poza ramy niniejszego artykułu. Z punktu widzenia prowadzonych rozważań istotne jest wskazanie, że ukształtowana została ona $\mathrm{w}$ taki sposób, by opracowanie programu polityki zdrowotnej bez uzyskania pozytywnego (lub warunkowo pozytywnego) stanowiska tego organu było niemożliwe ${ }^{38}$ (o czym dalej). Ewentualne wdrażanie negatywnie zaopiniowanego Prezesa AOTMiT s.p.p.z. wiąże się z naruszeniem dyscypliny finansów publicznych ${ }^{39}$.

\footnotetext{
${ }^{35}$ Por. art. 48a i n. u.ś.o.z.

${ }^{36}$ Por. art. 48a ust. 2 pkt 5, 7-11 u.ś.o.z., a także pkt 6, o ile projekt s.p.p.z. opracowywany jest na podstawie rekomendacji.

${ }^{37}$ Por. art. 48 a ust. 4 i ust. 5 u.ś.o.z.

${ }^{38}$ Opinia pozytywna jest konieczna przy pierwszym opracowaniu programu polityki zdrowotnej, a nie jest konieczna, gdy program polityki zdrowotnej, który wcześniej uzyskał pozytywną opinię, jest kontynuowany $\mathrm{w}$ niezmienionej formie, lub gdy jest realizowany zgodnie $\mathrm{z}$ wytycznymi (art. 48a ust. 5 pkt 1 lit „a” u.ś.o.z. oraz lit. „,b” tego ustępu w zw. z art. 48 aa 5 i 6 u.ś.o.z.).

${ }^{39}$ Por. art. 12a ustawy z dnia 17 grudnia 2004 r. o odpowiedzialności za naruszenie dyscypliny finansów publicznych, t.j. Dz.U. z 2021 r., poz. 289. W doktrynie pojawiły się głosy kwestionujące skuteczność tego rozwiązania - zob. J. FACON, Programy polityki zdrowotnej samorzadu terytorialnego na tle znamion art. 12 a ustawy o odpowiedzialności za naruszenie dyscypliny finansów publicznych, „Finanse Komunalne” 2020, nr 3, s. 30-41.
} 


\section{OPINIA PREZESA AOTMIT W PROCEDURZE OPRACOWYWANIA SAMORZĄDOWYCH PROGRAMÓW POLITYKI ZDROWOTNEJ}

W przypadku s.p.p.z. Prezes AOTMiT wydaje wiążącą j.s.t. opinię dotyczącą przedłożonego mu projektu ${ }^{40}$, kierując się kryteriami właściwymi kwalifikowaniu świadczeń opieki zdrowotnej jako gwarantowanych ${ }^{41}$. Dodatkowo, w razie finansowania za pomocą opiniowanego s.p.p.z. świadczeń gwarantowanych objętych programami zdrowotnymi bierze on także pod uwagę organizacyjną i merytoryczną spójność s.p.p.z. z tymi programami zdrowotnymi.

Pośród kryteriów kwalifikowania świadczeń zdrowotnych jako gwarantowanych, którymi ma kierować się Prezes, wyróżnić można dwa kryteria niemedyczne ${ }^{42}$, z których jedno ma charakter efektywnościowy (,stosunek kosztów do uzyskiwanych efektów zdrowotnych”) ${ }^{43}$, drugie zaś wskazuje na „skutki finansowe dla systemu ochrony zdrowia, w tym dla podmiotów zobowiązanych do finansowania świadczeń opieki zdrowotnej ze środków publicznych"44.

Zasadność stosowania kryterium efektywności kosztowej ${ }^{45}$ przy opiniowaniu programu polityki zdrowotnej wydaje się bezsporna, na co zwraca się uwagę tak $\mathrm{w}$ doktrynie, jak i judykaturze ${ }^{46}$. Jest bowiem rzeczą właściwą każdemu systemowi opieki zdrowotnej, że potrzeby przekraczają posiadane zasoby. Efektywność kosztowa jest zatem kryterium istotnym z punktu widzenia zasad gospodarowania środkami publicznymi ${ }^{47}$, również $\mathrm{w}$ zakresie świadczeń opieki zdrowotnej. Właśnie dbałością o efektywność dokonywanych wydatków uzasadniał ustawodawca obwarowanie wdrażania s.p.p.z.

40 Por. art. 48 a ust. 11 u.ś.o.z.

${ }^{41}$ Kryteria te zawarte są w art. 31 a ust. 1 u.ś.o.z.

${ }^{42}$ W doktrynie nazywane także „kosztowymi” - zob. D.E. LACH, Kryteria „kosztowe” kwalifikowania świadczeń opieki zdrowotnej jako gwarantowanych a prawo do ochrony zdrowia, „Ruch Prawniczy, Ekonomiczny i Socjologiczny” 79 (2017), nr 2, s. 74.

43 „Stosunek kosztów do uzyskiwanych efektów zdrowotnych” - art. 31a ust. 1 pkt 6 u.ś.o.z.

${ }^{44}$ Por. art. 31 a ust. 1 pkt 7 u.ś.o.z.

${ }^{45}$ Przy czym na potrzeby niniejszego artykułu pojęcia „koszt” i „wydatek” utożsamia się, jako określony transfer z publicznego zasobu środków pieniężnych na zewnątrz, celem sfinansowania danego świadczenia opieki zdrowotnej. Pojęcia te w kontekście świadczeń gwarantowanych można rozdzielić (zob. M. JEWCZAK, Koszyk świadczeń gwarantowanych, [w:] Finansowanie ochrony zdrowia. Wybrane zagadnienia, red. J. Suchecka, Warszawa: ABC a Wolters Kluwer business 2015, s. 253).

${ }^{46}$ Zob. D. LACH, Kryteria „kosztowe”, s. 84-85, a odnośnie do miernika efektywności przy ocenie świadczeń opieki zdrowotnej - wyrok Trybunału Konstytucyjnego z dnia 7 stycznia 2004 r., K 14/03, OTK-A 2004/1/1 oraz wyrok Sądu Najwyższego z dnia 9 czerwca 2005 r., III CK 626/04, OSNC 2006/6/89.

${ }^{47}$ Por. art. 44 ust. 3 pkt 1 lit. ,a” u.f.p. 
wbrew negatywnej opinii Prezesa AOTMiT odpowiedzialnością z tytułu naruszenia dyscypliny finansów publicznych ${ }^{48}$.

Drugie niemedyczne kryterium opiniowania odnieść można także do samorządu, ponieważ - jak już zostało wskazane - samorząd terytorialny obowiązany jest $\mathrm{w}$ pewnym zakresie do finansowania świadczeń opieki zdrowotnej ze środków publicznych. Niewątpliwie również samorząd ze swoimi zadaniami znajduje się $\mathrm{w}$ systemie ochrony zdrowia, choć rzecz jasna nie jest podmiotem jedynym i nie wyczerpuje w całej rozciągłości kryterium „całości systemu”49.

Ustawodawca nie precyzuje rozumienia użytego w omawianym kryterium oceny terminu „skutki finansowe”. Wydaje się on jednak możliwy do zdekodowania przy wykorzystaniu języka naturalnego i systemowego kontekstu prawnofinansowego. Słowo ,skutek” jest słowem potocznym i oznacza po prostu: następstwo ${ }^{50}$. Natomiast „finanse” na gruncie prawa finansowego (a także częściowo w rozumieniu potocznym) oznaczają procesy gromadzenia i wydatkowania środków pieniężnych oraz podmioty z tymi procesami zwią$z^{2} e^{51}$. Do „finansów” zaliczyć można więc także kwestie wydatkowania środków publicznych ${ }^{52}$.

Tak więc wydając opinię dotyczącą opracowywanego projektu programu polityki zdrowotnej, o której mowa w art. 48a ust. 4 u.ś.o.z., a maiori ad minus Prezes AOTMiT analizuje również skutki tego programu dla wydatków j.s.t. Teoretycznie możliwa jest zatem sytuacja, w której Prezes opierając się (jedynie lub między innymi) na przesłance skutków finansowych dla j.s.t. opracowującej program polityki zdrowotnej uzna, że program taki należy ocenić negatywnie w obszarze wydatków tej jednostki, na przykład sięgając po argumentację braku potrzeby wydatkowania określonych kwot na

${ }^{48}$ Druk nr 1791, Sejm Rzeczypospolitej Polskiej VIII kadencji, http://orka.sejm.gov.pl/ Druki8ka.nsf/0/F6F3FEDCCC377CA8C1258191003FCB9A/\%24File/1791.pdf [dostęp: 21.01.2021], s. 22-23 (s. 6-7 uzasadnienia), por. także: ustawa z dnia 29 września 2017 r. o zmianie ustawy o świadczeniach opieki zdrowotnej finansowanych ze środków publicznych oraz niektórych innych ustaw, Dz.U.2017.2110.

${ }^{49}$ Zob. P. Bromber [i in.], System ochrony zdrowia $w$ Polsce, Warszawa: CeDeWu 2015, s. 12-17. W pierwszej kolejności podmiotem takim będzie oczywiście Narodowy Fundusz Zdrowia.

${ }^{50}$ Por. https://sjp.pwn.pl/szukaj/skutek.html [dostęp: 20.01.2021].

${ }^{51}$ Por. K. Ostrowski, Prawo finansowe. Zarys ogólny, Warszawa: Państwowe Wydawnictwo Naukowe 1970 s. 13-14; J. JAŚKIEWICZOWA, Z. JAŚKIEWICZ, Zarys nauki finansów publicznych, Warszawa: Państwowe Wydawnictwo Ekonomiczne 1968, s. 16; A. MierzwA, Art. 3, [w:] Ustawa o finansach publicznych. Komentarz, red. P. Smoleń, Warszawa: C.H. Beck 2012, s. 63, a także art. 3 u.f.p. wprowadzający normatywną definicję finansów publicznych.

${ }^{52}$ Por. art. 3 pkt 2 u.f.p. 
s.p.p.z. z uwagi na inne, potrzebniejsze wydatki w sferze ochrony zdrowia (lub jakimkolwiek innym zakresie) ${ }^{53}$. Programu takiego wówczas nie można by wdrożyć.

Co więcej, opinia co do projektu s.p.p.z. wydawana jest przez Prezesa AOTMiT ex ante. Dlatego, oraz $\mathrm{z}$ uwagi na niezgodność podmiotową i przedmiotową $\mathrm{z}$ art. 171 ust. 1 Konstytucji, nie jest ona środkiem nadzoru. Natomiast u.ś.o.z., wskazując na niemedyczną przesłankę skutków finansowych dla j.s.t. jako kryterium opiniowania s.p.p.z., nie ogranicza Prezesa AOTMiT co do możliwego spektrum jej stosowania. Innymi słowy, nie istnieją przepisy, które zawężałyby to stosowanie jedynie pod kątem kryterium legalności (jak ma to miejsce wobec spraw finansowych samorządu terytorialnego przy czynnościach nadzorczych $\mathrm{RIO}^{54}$ ). Jakichkolwiek precyzujących wskazówek co do interpretacji terminu "skutków finansowych" nie zawiera także uzasadnienie projektu ustawy, w którym (wraz z samym koszykiem świadczeń gwarantowanych i kryteriami ich kwalifikowania) wprowadzano obowiązek opiniowania s.p.p.z. ${ }^{55}$ przy zastosowaniu kryteriów właściwych świadczeniom gwarantowanym ${ }^{56}$.

\section{WNIOSKI}

Skoro decyzja o przeznaczeniu przez j.s.t. środków publicznych na realizację samorządowego programu polityki zdrowotnej objęta będzie samodzielnością wydatkowania tej j.s.t., a przeznaczone na ten program środki pieniężne stanowić będą ujęty w uchwale budżetowej wydatek, to nadzór nad nim sprawowany może być na płaszczyźnie finansowej jedynie przez RIO (sama zaś uchwała stanowiąca podstawę realizowania s.p.p.z. podlegać będzie nadzorowi wojewody). Jedynym stosowanym kryterium nadzorczym jest wówczas kryterium legalności.

Tymczasem wydanie przez Prezesa AOTMiT negatywnej opinii o projekcie samorządowego programu polityki zdrowotnej z uwagi na przesłankę skutków finansowych jego realizacji przez j.s.t. de facto powstrzymuje finansowanie

\footnotetext{
${ }^{53}$ Opinia mogłaby także opierać się na argumentacji, że dana j.s.t. nie posiada odpowiednich zasobów pieniężnych na realizację programu polityki zdrowotnej lub że realizacja taka zagrażałaby realizacji innego s.p.p.z.

${ }^{54}$ Por. art. 171 ust. 2 Konstytucji RP.

${ }^{55}$ Wówczas nazywanych jeszcze ,programami zdrowotnymi”. Jedną z kolejnych nowelizacji u.ś.o.z. terminologię uporządkowano.

${ }^{56}$ Druk nr 1590, passim.
} 
tego programu. Skutkuje to także naruszeniem samodzielności wydatkowania j.s.t., przedkładającej program w procedurze opiniowania. $\mathrm{Z}$ uwagi bowiem na konstytucyjnie określone granice nadzoru nad samorządem terytorialnym nie ma możliwości, by jakikolwiek organ władzy publicznej ingerował ex ante w decyzje wydatkowe j.s.t., podejmowane na gruncie prawa do samodzielności wydatkowania środków publicznych, stanowiącego element samodzielności finansowej. Wyraźnego podkreślenia wymaga, że do naruszenia dojdzie tylko wówczas, gdy podstawą negatywnego stanowiska Prezesa AOTMiT będzie zastosowanie przesłanki skutków finansowych dla j.s.t., a nie inne przesłanki medyczne lub niemedyczna przesłanka efektywnościowa. Jedynie bowiem RIO, ex post, może władczo ingerować w samodzielność wydatkowania j.s.t., i tylko z uwzględnieniem kryterium, na skutek sprawowanego nadzoru.

Mając na uwadze powyższe, trzeba jednak zwrócić uwagę, że wprowadzenie przez ustawodawcę odpowiedzialności za naruszenie dyscypliny finansów publicznych w przypadku realizowania programu negatywnie zaopiniowanego przez Prezesa AOTMiT, podyktowane było chęcią zapewnienia gospodarnego wydatkowania środków publicznych. Nacisk położono zatem na przesłankę efektywności kosztowej s.p.p.z. Rozwiązanie takie zasługuje na aprobatę, w szczególności uwzględniając szereg towarzyszących mu procedur mających uprościć realizację programów już zaopiniowanych lub zgodnych z rekomendacjami Prezesa AOTMiT. Wskazana i dotycząca drugiej przesłanki niemedycznej sprzeczność wydaje się być spowodowana dokonanym pierwotnie odesłaniem w procedurze opiniowania samorządowych programów polityki zdrowotnej do kryteriów kwalifikowania świadczeń opieki zdrowotnej jako gwarantowanych. Rozwiązanie takie ustawodawca wprowadził do u.ś.o.z. wraz z wdrażaniem koszyka świadczeń gwarantowanych. Zabrakło wówczas holistycznej, systemowej oceny przyjmowanej regulacji pod kątem relacji z samodzielnością finansową j.s.t.

Zasadne zdaje się być w związku $\mathrm{z}$ tym sformułowanie postulatu de lege ferenda co do zmodyfikowania ${ }^{57}$, a być może nawet usunięcia przesłanki skutków finansowych dla systemu ochrony zdrowia (w tym podmiotów zobowiązanych do finansowania świadczeń opieki zdrowotnej ze środków publicznych), jako kryterium opiniowania samorządowego programu polityki zdrowotnej przez Prezesa AOTMiT. Rolą tego organu, szczególnie widoczną

${ }^{57}$ Zwraca uwagę zwłaszcza brak obowiązku szczegółowego uzasadnienia opinii Prezesa AOTMiT. Zasadne wydaje się, by przynajmniej opinia negatywna obwarowana była wymogiem szczegółowego jej uzasadnienia. 
w jego konstrukcji, jest bowiem troska o należyty poziom medycznej skuteczności oraz związaną z nim należytą proporcję kosztów do efektów zdrowotnych, nie zaś wkraczanie w obszar samodzielności wydatkowania samorządów, podlegający nadzorowi $\mathrm{RIO}^{58}$.

\section{BIBLIOGRAFIA}

\section{ŹRÓDŁA PRAWA}

Konstytucja Rzeczypospolitej Polskiej z dnia 2 kwietnia 1997 r., Dz.U. Nr 78, poz. 483 z późn. zm. Ustawa z dnia 8 marca 1990 r. o samorządzie gminnym, t.j. Dz.U. z 2020 r., poz. 713 z późn. zm.

Ustawa z dnia 7 października 1992 r. o regionalnych izbach obrachunkowych, t.j. Dz.U. z 2019 r., poz. 2137.

Ustawa z dnia 5 czerwca 1998 r. o samorządzie powiatowym, t.j. Dz.U. z 2020 r., poz. 920.

Ustawa z dnia 5 czerwca 1998 r. o samorządzie województwa, t.j. Dz.U. z 2020 r., poz. 1668 z późn. zm.

Ustawa z dnia 27 sierpnia 2004 r. o świadczeniach opieki zdrowotnej finansowanych ze środków publicznych, t.j. Dz.U. z 2021 r., poz. 1285.

Ustawa z dnia 17 grudnia 2004 r. o odpowiedzialności za naruszenie dyscypliny finansów publicznych, t.j. Dz.U. z 2021 r., poz. 289.

Ustawa z dnia 27 sierpnia 2009 r. o finansach publicznych, t.j. Dz.U. z 2021 r., poz. 305.

Ustawa z dnia 15 kwietnia 2011 r. o działalności leczniczej, t.j. Dz.U. z 2021 r., poz. 711.

Ustawa z dnia 29 września 2017 r. o zmianie ustawy o świadczeniach opieki zdrowotnej finansowanych ze środków publicznych oraz niektórych innych ustaw, Dz.U.2017.2110.

\section{PROJEKTY AKTÓW PRAWNYCH}

Druk nr 1590, Sejm Rzeczypospolitej Polskiej VI kadencji, http://orka.sejm.gov.pl/Druki6ka.nsf/ 0/097002D1CC0F4D2DC12575450030C90B/\$file/1590.pdf [dostęp: 3.02.2021].

Druk nr 1791, Sejm Rzeczypospolitej Polskiej VIII kadencji, http:/orka.sejm.gov.pl/Druki8ka.nsf/ 0/F6F3FEDCCC377CA8C1258191003FCB9A/\%24File/1791.pdf [dostęp: 21.01.2021].

\section{LITERATURA}

BiAŁYNICKI-BIRULA Paweł: Zmiany w systemie finansowania ochrony zdrowia w Polsce. Perspektywa międzynarodowa, Kraków: Wydawnictwo Uniwersytetu Ekonomicznego w Krakowie 2006.

${ }^{58}$ A w dalszej perspektywie - sądownictwa administracyjnego. Zob. szerzej: M. SzwAST, Postulaty zmian $w$ zakresie wybranych aspektów rządowej i społecznej kontroli nad działalnościa uchwałodawcza jednostek samorzadu terytorialnego, „Zeszyty Naukowe Sądownictwa Administracyjnego" 16 (2020), nr 1, s. 11-28. System kontroli instancyjnej nadzoru RIO nie jest to system pozbawiony wad, na co wskazuje autor powołanego artykułu. 
BORODO Andrzej: Procedury w zakresie wydatków budżetowych jednostek samorządu terytorialnego - wybrane aspekty prawne, [w:] Księga jubileuszowa ku czci Profesor Krystyny Sawickiej, red. Wiesława Miemiec, Wrocław: Oficyna Wydawnicza UNIMEX 2017, s. 343-352.

Bromber Piotr [i in.]: System ochrony zdrowia w Polsce, Warszawa: CeDeWu 2015.

CHADAŁa Piotr: Samodzielność finansowa jednostek samorządu terytorialnego, „Annales Universitatis Mariae Curie-Skłodowska", Sectio H, Oeconomia 2002, nr 36, s. 227-245.

FACON Janusz: Programy polityki zdrowotnej samorządu terytorialnego na tle znamion art. 12a ustawy o odpowiedzialności za naruszenie dyscypliny finansów publicznych, „Finanse Komunalne" 2020, nr 3, s. 30-41.

GLINECKA Jolanta: Zasady polskiego prawa dochodów samorządu terytorialnego, Bydgoszcz: Oficyna Wydawnicza Branta 2001.

GLUMIŃSKA-PAwLIC Jadwiga: Samodzielność finansowa jednostek samorządu terytorialnego w Polsce. Studium prawnofinansowe, Katowice: Wydawnictwo Uniwersytetu Śląskiego 2003.

https://sjp.pwn.pl/szukaj/skutek.html [dostęp: 20.01.2021]

JAŚKIEWICZOWA Jadwiga, JAŚKIEWICZ Zbigniew: Zarys nauki finansów publicznych, Warszawa: Państwowe Wydawnictwo Ekonomiczne 1968.

JEWCZAK Maciej: Koszyk świadczeń gwarantowanych, [w:] Finansowanie ochrony zdrowia. Wybrane zagadnienia, red. Jadwiga Suchecka, Warszawa: ABC a Wolters Kluwer business 2015, s. $242-276$.

KISAŁA Magdalena: Skuteczność jako determinanta działań jednostek samorządu terytorialnego, „Studia Prawnicze KUL” 2019, nr 2, s. 179-199.

KORNBERGER-SOKOŁOWSKA Elżbieta: Zasada proporcjonalności a ochrona samodzielności finansowej jednostek samorządu terytorialnego, [w:] Prawo finansowe samorządu terytorialnego. Prawo finansowe wobec wyzwań XXI wieku, red. Jolanta Gliniecka [i in.], GdańskNynäshamn-Sztokholm: CeDeWu 2013, s. 35-40.

KopAŃSKA Agnieszka [i in.]: Autonomia fiskalna i jej wpływ na działania samorządów, Warszawa: Wydawnictwo Naukowe SCHOLAR 2018.

KoTULSKI Mariusz: Samorząd terytorialny w dwudziestoleciu międzywojennym, „Acta Universitatis Wratislaviensis". Prawo 2019, nr 327, s. 129-153.

KuCIA-GuŚCIORA Beata: Wybrane instrumenty oddziaływania ministra właściwego do spraw finansów publicznych na gospodarkę finansową jednostek samorządu terytorialnego, [w:] Księga jubileuszowa ku czci Profesor Krystyny Sawickiej, red. Wiesława Miemiec, Wrocław: Oficyna Wydawnicza UNIMEX 2017, s. 123-137.

LACH Daniel E.: Kryteria „kosztowe” kwalifikowania świadczeń opieki zdrowotnej jako gwarantowanych a prawo do ochrony zdrowia, „Ruch Prawniczy, Ekonomiczny i Socjologiczny” 79(2017), nr 2, s. 73-85.

LENIO Paweł: Publicznoprawne źródła finansowania systemu ochrony zdrowia, Warszawa: Wolters Kluwer 2018.

MĄCZYŃSKi Marek: Pojęcie zadania publicznego a zadania samorządu terytorialnego, „Finanse Komunalne" 2019, nr 1-2, s. 105-112.

Mierzwa Andrzej: Art. 3, [w:] Ustawa o finansach publicznych. Komentarz, red. Paweł Smoleń, Warszawa: C.H. Beck 2012, s. 63-79.

OstrowsKi Karol: Prawo finansowe. Zarys ogólny, Warszawa: Państwowe Wydawnictwo Naukowe 1970. 
PONIATOwiCz Marzanna: Determinanty autonomii dochodowej samorządu terytorialnego w Polsce, „Financial Sciences - Nauki o Finansach” 24 (2015), nr 1 (22), s. 11-30.

RYBARSKI Roman: Nauka Skarbowości, Warszawa: Wolters Kluwer 2015 (reprint).

SALACHNA Joanna M.: Granice samodzielności legislacyjnej jednostek samorządu terytorialnego, Gdańsk: Ośrodek Doradztwa i Doskonalenia Kadr 2012.

SAlachna Joanna M.: Funkcja ustrojowa Regionalnych Izb Obrachunkowych, „Finanse Komunalne" 2018, nr 12, s. 7-15.

SURówKA Krzysztof: Samodzielność finansowa samorządu terytorialnego w Polsce, Warszawa: Polskie Wydawnictwo Ekonomiczne 2013.

ŚwITAL Paweł: Prawo miejscowe jako podstawa funkcjonowania lokalnej wspólnoty samorządowej, ,Samorząd Terytorialny” 2019, nr 11, s. 28-37.

SYlweSTRZAK Andrzej: Regionalne Izby Obrachunkowe w III Rzeczypospolitej Polskiej, „Gdańskie Studia Prawnicze" 2002, nr 8, s. 81-104.

SzWAST Michał: Postulaty zmian w zakresie wybranych aspektów rządowej i społecznej kontroli nad działalnością uchwałodawczą jednostek samorządu terytorialnego, „Zeszyty Naukowe Sądownictwa Administracyjnego" 16 (2020), nr 1, s. 9-29.

ZAWORA Jolanta: Samodzielność finansowa samorządu gminnego, Rzeszów: Wydawnictwo Uniwersytetu Rzeszowskiego 2008.

\section{ORZECZNICTWO}

Wyrok Trybunału Konstytucyjnego z dnia 7 stycznia 2004 r., K 14/03, OTK-A 2004/1/1.

Wyrok Sądu Najwyższego z dnia 9 czerwca 2005 r., III CK 626/04, OSNC 2006/6/89

\section{SAMODZIELNOŚĆ WYDATKOWANIA ŚRODKÓW PUBLICZNYCH A SAMORZĄDOWY PROGRAM POLITYKI ZDROWOTNEJ}

Streszczenie

W obrębie samodzielności finansowej jednostki samorządu terytorialnego (j.s.t.) ponosząc wydatki na zadania własne, korzystają z konstytucyjnej samodzielności wydatkowania. Nie jest ona nieograniczona i podlega nadzorowi regionalnych izb obrachunkowych. Nadzór ten sprawowany jest na podstawie kryterium legalności, a jakakolwiek ingerencja władcza w decyzję j.s.t. nastąpić może dopiero ex post. W szczególności nie jest dopuszczalna ingerencja w decyzje finansowe samorządu w sferze wydatkowania na etapie podejmowania tych decyzji.

Wykonując zadania własne z zakresu ochrony zdrowia, j.s.t. opracowują, wdrażają i realizują samorządowe programy polityki zdrowotnej (s.p.p.z.). W procedurze opracowywania projektu s.p.p.z. podlega on opiniowaniu przez Prezesa Agencji Oceny Technologii Medycznych i Taryfikacji (nadzorowanego przez ministra właściwego do spraw zdrowia). Jednym ze stosowanych podczas tego opiniowania kryteriów jest kryterium skutków finansowych dla jednostek samorządu terytorialnego. Negatywna opinia uniemożliwia realizację samorządowego programu polityki zdrowotnej. Ponieważ opinia taka dokonywana jest ex ante, jej oparcie na kryterium skutków finansowych dla j.s.t. powoduje systemową niespójność z samodzielnością wydatkowania j.s.t., nadzorowaną jedynie ex post przez regionalną izbę obrachunkową. 
Dostrzegając ogólną zasadność uczestnictwa Prezesa AOTMiT w procedurze oceny samorządowych programów polityki zdrowotnej, w artykule sfomułowano wnioski de lege ferenda zmierzające do zniwelowania obserwowanej niekoherencji.

Słowa kluczowe: ochrona zdrowia; samorząd terytorialny; samodzielność finansowa; samodzielność wydatkowa; programy polityki zdrowotnej; nadzór nad samorządem terytorialnym

\section{PUBLIC SPENDING DISCRETION \\ AND THE LOCAL GOVERNMENT HEALTH CARE POLICY PROGRAM}

\section{S u m m a ry}

Local government units (abbrev.: l.g.u.) bear expenses on their own tasks under public spending discretion - a rule within the constitutional financial independence. However, spending discretion is not unfettered and is subject to supervision of regional chambers of audit (Polish: "regionalne izby obrachunkowe"). The supervision is based on legality critierion. Any interference with the 1.g.u.'s decision is allowed only ex post. In particular, it is not permitted to interfere within the spending decisions of local government on the at the decision-making stage.

Performing tasks related to health care, l.g.u. draw up, implement and carry out local government health care policy programs. At the drawing up stage, the program is assessed by the President of the Agency of Health Care Technology Assessment and Tariff System (Polish: "Agencja Oceny Technologii Medycznych i Taryfikacji", Polish abbrev.: AOTMiT; agency is supervised by the minister responsible for health care issues). Assessing, the AOTMiT's President applies criterion of financial implications to the local government unit. Negative assessment prevents 1.g.u. from carrying out the program. Such assessment, being done ex ante, results in systemic incoherence with the spending discretion, since the spending discretion is supervised and may be interfered only by regional chamber of audit, considering legality criterion.

Thus, de lege ferenda conclusions were formulated to overcome the said incoherence, recognizing general purposefulness of involving AOTMiT's President in the procedure of assessing local government health care policy programs.

Keywords: health care; local government; financial independence; spending discretion; local government health care policy programs; local government supervision 